\title{
In vitro Evaluation of Fungicides against Blast of Foxtail Millet caused by Pyricularia setariae
}

\author{
B. Mallikarjuna*, M. S. Nagaraj and K. B. Palanna \\ Department of Plant Pathology, College of Agriculture, GKVK, Bengaluru, India \\ *Corresponding author
}

\begin{abstract}
Keywords
Fungicide, Mycelial growth, Per cent inhibition, Poisoned food technique, Pyricularia setariae

Article Info

Accepted:

18 January 2020

Available Online:

10 February 2020
\end{abstract}

\section{A B S T R A C T}

The present In-vitro study was conducted at pathology laboratory, University of agricultural sciences, ZARS, GKVK, Bangalore, Karnataka, India during march to evaluate fungicides against foxtail millet blast disease caused by Pyricularia setariae. The ten different systemic fungicides, four contact and three combi product fungicides were tested at three different concentrations by using the poisoned food technique. Among the ten different systemic fungicides, highest per cent inhibition (100\%) of mycelial growth of fungus was recorded in propiconozole, hexaconozole and carbendazimat all concentration followed by tebuconozole. Among contact fungicides mancozeb, capton and copper oxychloride found effective and all the tested combi products found effective against $P$. setariae.

\section{Introduction}

Foxtail millet [Setaria italic (L.)Beauv.] is an ancient cultivated crop and most economically important species of the genus Setaria belongs to family poaceae and Native to China (Vavilov, 1926). This crop has high importance as it is a rich source of nutrients and grown for both food and fodder purpose. It is also known by several other names such as German millet, Italian millet, Chinese millet and Hungarian millet (Baker, 2003). It ranks $2^{\text {nd }}$ in the total world production of millets and continues to have an important place in the world agriculture providing around six million tons of food to millions of world population, mainly on marginal or poor soils in Southern Europe and in temperate, subtropical and tropical Asia (Marathee, 1993). It is widely grown throughout Africa, China, India, Russia, and the United States.

In India foxtail millet is grown on about 1 million ha, mainly in northern Karnataka, parts of costal Andhra Pradesh, Uttarakhand, Tamil Nadu, and some parts of the 
northeastern states. The grain is used as both food and fodder. It is a good source of carbohydrate, protein and essential amino acids and it is a very good datary component for diabetic and heart patients because it contains magnesium (Marathee, 1993). The grains are good source of protein, minerals (calcium, iron, potassium, magnesium and zinc) and vitamins (Rai, 2002). It is widely used as an energy source for pregnant, lactating women, sick people and children (Sema and Sarita, 2002). It has got medicinal value as it is used as curative for rheumatism and measles (Wright and Finch, 1962) and also it has been suggested that foxtail millet is used as a food component to cardiovascular diseases and type 2 diabetes (Choi et al., 2005).

Although foxtail millet has high nutritional importance and grown for both food and fodder purpose, the crop is affected by several biotic and abiotic constraints. Among the biotic constraints fungal diseases like leaf blast, brownspot, rust, downy mildew and bacterial diseases like bacterial streak are limiting the production of the crop. Among these diseases, blast caused by the fungus Pyricularia setariae Sacc. (teleomorph: Magnaporthe setariae)is the most destructive disease and affects both forage and grain production of foxtail millet. Symptoms of the disease appear as circular spots with straw colored centers on leaf blades. The spots are small and scattered, 2 to $5 \mathrm{~mm}$ in diameter and surrounded by a dark brown margin. When the disease appears in severe form during humid weather conditions, especially with a dense plant stand, the leaves wither and dry. Plants are infected at all growth stages (Gaikwad and D' Souza, 1987); lower leaves are the most severely affected.

Recognizing the importance of foxtail millet and the constraint caused by the leaf blast disease, the present study was planned toevaluate different fungicides under in vitro condition to generate primary data on effective fungicides against $P$. setariae.

\section{Materials and Methods}

In vitro evaluation of the fungicides for their effect on the growth of fungus was done by the Poison food technique (Nene and Thapliyal, 1973). The different fungicides tested are listed in table 1

The PDA media has been prepared and sterilized in an autoclave. The medium was cooled to $40^{\circ} \mathrm{C}$. The stock solution was made by dissolving fungicide in distilled water and the stock solution of each fungicide filter sterilized. An appropriate amount of stock solution was added to the medium, to obtain a required concentration and the conical flasks were gently shaken to completely disperse the fungicide solution. About 15-20 mL of poisoned media was poured into $90 \mathrm{~mm}$ Petri dishes and the plates were turned clockwise for even distribution of the media. The active growth culture was cut in aseptic conditions using a cork borer and transferred to the center of each Petri dish containing the poisoned medium. A control was maintained in which the fungal pathogen was grown under similar conditions on agar medium without any fungicide. The inoculated plates were incubated at $27 \pm 1^{\circ} \mathrm{C}$ for fourteen days and radial growth of the $P$. setariae was recorded in three directions and the average diameter was calculated. The per cent inhibition of growth over control was determined (Vincent, 1947)

$$
\begin{aligned}
& \mathrm{I}=\quad \begin{array}{l}
(\mathrm{C}-\mathrm{T}) \\
\text { Where., }
\end{array} \\
& \mathrm{I}=\text { Per cent inhibition. of mycelium } \\
& \mathrm{C}=\text { Growth of my.celium in control } \\
& \mathrm{T}=\text { Growth of mycelium in treatment }
\end{aligned}
$$




\section{Statistical analysis}

The data generated by different experiments were analyzed using the WASP software developed by ICAR- Central Coastal Agricultural Research Institute, Goa and the inferences were made with a probability of one and five percent for laboratory and field experiments respectively.

\section{Results and Discussion}

Ten systemic fungicides were tested at three (50, 100 and $200 \mathrm{ppm})$ concentration against P.setariae under in vitro condition by using poisoned food technique. Among these systemic fungicides propiconozole, hexaconozole and carbendazim inhibited maximum mycelial growth $(100 \%)$ at all concentrations followed by tebuconozole which accounted 100 per cent mycelial growth at $100 \mathrm{ppm}$ and $200 \mathrm{ppm}$ whereas least mycelial growth inhibition was observed in case of thifluzamide (14.69\%) at 50ppm (Table 2, plate 1, fig 1).

Triazole group of fungicides were found effective those inhibited the mycelia growth completely except difenconazole $(65.20 \%$ at 200 ppm). Similarly, Mohan et al., (2011) evaluated different fungicides against $P$. grisea and found tebuconazole, propiconazole, difenconazole and tricyclazole significantly effective over others. Several other workers (Gohel et al., 2008; Bhojyanaik, 2014; and Netam et al., 2014) also found both contact and systemic fungicides as effective in inhibiting the growth of Pyricularia. Somashekhar Konda (2015) reported that triazole group fungicides were effective against $P$. setariae.

Four contact and three combi-product fungicides were tested.at three concentrations viz., 250, 500 and 1000 ppm by using poisoned food technique.as described in material and method under in vitro condition. Among three combi product fungicides mancozeb + carbendazim excerted highest mycelial growth inhibition $(100 \%)$ at all concentrations followed by trifloxystrobin + tebuconazole which accounted 100 per cent inhibition at $500 \mathrm{ppm}$ and $1000 \mathrm{ppm}$, cymoxanil + mancozeb showed 100 per cent inhibition only at $1000 \mathrm{ppm}$ concentration. Among four contact fungicides mancozeb, capton and coppeoxychloride showed highest mycelial inhibition $(100 \%)$ at $1000 \mathrm{ppm}$ concentration and lowest inhibition was observed in chlorothalonil (73.82 \%) at 1000 ppm (Table 3, plate 2, fig 2).

In the absence of resistant cultivars and when there is sudden epidemic of the disease, use of fungicides is the only alternative method for controlling the diseases of crops. Hence, fungicides are the important components of integrated disease management practices. Evaluation of fungicides under in vitro condition is a convenient tool to screen a large number of fungicides and these can serve as guide for testing fungicides in field condition. The results of in vitro evaluation of fungicides studies revealed that among the contact fungicides, mancozeb, capton and copper oxy chloride were found most effective fungicides showing cent per cent inhibition of growth at $1000 \mathrm{ppm}$. The findings agree with Hajano et al., (2012) who reported that among the fungicides tested mancozeb was the highly effective fungicide restricting the complete mycelia growth of $P$. oryzae. Anwar et al., (2002) also observed that mancozeb exhibited excellent control of rice blast disease caused by M. oryzae.

All the combi product fungicides tested found to inhibit 100 per cent of the growth. The result agrees with Mohan et al., (2011) reported that. azoxystrobin + difenconazole found effective against P.oryzae, Somashekhar Konda (2015) reported that mancozeb + carbendazim found effective among combi product fungicides tested against $P$. setariae. 
Table.1 Fungicides used against $P$. setariae in poison food technique

\begin{tabular}{|c|c|c|c|}
\hline SI No. & Common name & Trade name & Chemical name \\
\hline \multicolumn{4}{|c|}{ Contact fungicides } \\
\hline 1 & Mancozeb & $\begin{array}{l}\text { Dithane M-45 75\% } \\
\text { WP }\end{array}$ & Manganese ethylene bisdithiocarbamate \\
\hline 2 & Chlorothalonil & Kavach $75 \%$ WP & Tetrachloroisophthalonitrile \\
\hline 3 & Captan & Captaf 50\% WP & $\begin{array}{l}\mathrm{N} \text {-(Trichloromethylthio-4-cyclohexane-1,2, } \\
\text { dicarboximide) }\end{array}$ \\
\hline 4 & Copper oxychloride & Blitox 50\% WP & Copper oxy-chloride \\
\hline \multicolumn{4}{|c|}{ Combiproducts } \\
\hline 1 & $\begin{array}{l}\text { Cymoxamil + } \\
\text { Mancozeb }\end{array}$ & $\begin{array}{l}\text { Moximate }(8 \%+ \\
64 \%) \text { WP }\end{array}$ & 1-(2-cyano-2-methoxyiminoacetyl)-3-ethylurea \\
\hline 2 & $\begin{array}{l}\text { Carbendazim }+ \\
\text { Mancozeb }\end{array}$ & $\begin{array}{l}\text { Saaf }(12 \%+63 \%) \\
\text { WP }\end{array}$ & $\begin{array}{l}\text { Methyl } 2 \text { benzimidazolecarbamate }+ \text { Manganese } \\
\text { ethylene bisdthiocarbomate }\end{array}$ \\
\hline 3 & $\begin{array}{l}\text { Tebuconazole }+ \\
\text { Trifloxystrobin }\end{array}$ & $\begin{array}{l}\text { Nativo }(50 \%+25 \%) \\
\text { WG }\end{array}$ & $\begin{array}{l}\text { 1-(4-Chlorphenyl)-4,4-dimethyl-3-[1,2,4]triazol- } \\
\text { 1-ylmethyl-pentan-3-ol + (E,E)-methoxyimino- } \\
\{2-\{1 \text {-[3-trifluoromethyl-phenyl- } \\
\text { ethyllideneaminooxymethyl]-phenyl }\} \text { acetic acid } \\
\text { methyl ester }\end{array}$ \\
\hline \multicolumn{4}{|c|}{ Systemic fungicides } \\
\hline 1 & Azoxystrobin & Amistar 23\% EC & $\begin{array}{l}\text { Methyl (E)-2-[[6-(2-cyanophenoxy)-4- } \\
\text { pyrimidinyl]oxy]- } \alpha \text { - } \\
\text { (methoxymethylene)benzeneacetate }\end{array}$ \\
\hline 2 & Carbendazim & Bavistin 50\% WP & Methyl 2 benzimidazolecarbamate \\
\hline 3 & Difenconazole & Score $25 \% \mathrm{EC}$ & $\begin{array}{l}\text { 1-(2-(2-chloro-4-(4 chlorophenoxy)phenyl)-4 } \\
\text { methyl-1,3-dioxolan-2-methyl)-1H-1,2,4-triazole }\end{array}$ \\
\hline 4 & Hexaconazole & Contaf5\% EC & $\begin{array}{l}\text { RS-2-(2,4-D)-1-(1H-1, 2,4 Triazole-1-yl) hezan } \\
\text { 2-ol }\end{array}$ \\
\hline 5 & Propiconazole & Tilt $25 \%$ EC & $\begin{array}{l}\text { (RS)-2-(2,4-dichlorophenyl)-1-(1H-1, 2,4- } \\
\text { triazole-1-yl) prope-2-Ol }\end{array}$ \\
\hline 6 & Tebuconazole & Folicur $25 \%$ EC & $\begin{array}{l}\alpha \text {-[2-(4-chlorophenyl)ethyl]- } \alpha \text {-(1,1- dimethyl)- } \\
1 \mathrm{H}-1,2,4 \text {-triazole-1-ethanol }\end{array}$ \\
\hline 7 & Pyraclostrobin & Headline $20 \%$ EC & $\begin{array}{l}\text { [2-(\{[1-(4-chlorophenyl)-1H-pyrazol-3- } \\
\text { yl]oxy\}methyl)phenyl]methoxycarbamic acid. }\end{array}$ \\
\hline 8 & Thifluzamide & Pulsor $24 \%$ SC & $\begin{array}{l}\text { 2,6-diobromo-2-methyl-4'-trifluoromethyox-4- } \\
\text { trifluoromethyl-1,3-thiazole-5-carboxanilide }\end{array}$ \\
\hline 9 & Trifloxystrobin & Flint $50 \%$ WG & $\begin{array}{l}\text { methyl }(\alpha E)-\alpha \text {-(methoxyimino)-2-[[[(E)-[1-[3- } \\
\text { (trifluoromethyl)phenyl]ethylidene] } \\
\text { amino]oxy]methyl]benzeneacetate }\end{array}$ \\
\hline 10 & Tricyclazole. & Beam $75 \% \mathrm{WP}$ & $\begin{array}{l}\text { 5-methyl-1,.2,4-triazolo[ }[3,4- \\
\text { b][1,3]benzothiazole. }\end{array}$ \\
\hline
\end{tabular}


Table.2 In vitro efficacy of systemic fungicides on $P$. setariae

\begin{tabular}{|c|c|c|c|c|c|}
\hline \multirow[t]{3}{*}{ SI No } & \multirow[t]{3}{*}{ Fungicides } & \multirow{2}{*}{\multicolumn{3}{|c|}{$\begin{array}{c}\text { Per cent inhibition of mycelial growth } \\
\text { Concentration (ppm) }\end{array}$}} & \multirow[t]{3}{*}{ Mean } \\
\hline & & & & & \\
\hline & & $\mathbf{5 0}$ & 100 & 200 & \\
\hline 1 & Pyraclostrobin $20 \%$ WG & $\begin{array}{c}31.81 \\
(34.33)\end{array}$ & $\begin{array}{c}42.85 \\
(40.89)\end{array}$ & $\begin{array}{c}57.71 \\
(49.44)\end{array}$ & 44.12 \\
\hline 2 & Trifloxystrobin $50 \%$ WG & $\begin{array}{c}40.80 \\
(39.70)\end{array}$ & $\begin{array}{c}48.66 \\
(44.23)\end{array}$ & $\begin{array}{c}64.69 \\
(53.55)\end{array}$ & 51.38 \\
\hline 3 & Azoxystrobin $25 \%$ EC & $\begin{array}{c}32.06 \\
(34.49)\end{array}$ & $\begin{array}{c}41.90 \\
(40.34)\end{array}$ & $\begin{array}{c}51.87 \\
(46.07)\end{array}$ & 41.94 \\
\hline 4 & Thifluzamide $24 \%$ SC & $\begin{array}{c}14.69 \\
(22.54)\end{array}$ & $\begin{array}{c}28.79 \\
(32.45)\end{array}$ & $\begin{array}{c}34.54 \\
(35.99)\end{array}$ & 26.01 \\
\hline 5 & Corbendazim 50\% WP & $\begin{array}{l}100.00 \\
(90.00)\end{array}$ & $\begin{array}{l}100.00 \\
(90.00)\end{array}$ & $\begin{array}{l}100.00 \\
(90.00)\end{array}$ & 100.00 \\
\hline 6 & Tebuconozole $25.9 \%$ EC & $\begin{array}{c}85.84 \\
(67.89)\end{array}$ & $\begin{array}{l}100.00 \\
(90.00)\end{array}$ & $\begin{array}{l}100.00 \\
(90.00)\end{array}$ & 95.28 \\
\hline 7 & Propiconozole 25\% EC & $\begin{array}{l}100.00 \\
(90.00)\end{array}$ & $\begin{array}{l}100.00 \\
(90.00)\end{array}$ & $\begin{array}{l}100.00 \\
(90.00)\end{array}$ & 100.00 \\
\hline 8 & Hexaconozole 5\% EC & $\begin{array}{l}100.00 \\
(90.00)\end{array}$ & $\begin{array}{l}100.00 \\
(90.00)\end{array}$ & $\begin{array}{l}100.00 \\
(90.00)\end{array}$ & 100.00 \\
\hline 9 & Difenconozole $25 \%$ EC & $\begin{array}{c}37.61 \\
(37.83)\end{array}$ & $\begin{array}{c}60.23 \\
(50.91)\end{array}$ & $\begin{array}{c}65.20 \\
(53.85)\end{array}$ & 54.35 \\
\hline 10 & Tricyclozole $75 \%$ WP & $\begin{array}{c}26.88 \\
(43.278)\end{array}$ & $\begin{array}{c}43.76 \\
(44.249)\end{array}$ & $\begin{array}{c}70.64 \\
(44.33)\end{array}$ & 47.09 \\
\hline & Control & 0.0 & 0.0 & 0.0 & 0.0 \\
\hline & & Fung & e(F) & $\begin{array}{c}\text { Concentration } \\
\text { ( C ) }\end{array}$ & $\mathbf{F} \times \mathbf{C}$ \\
\hline & $\mathrm{SE}(\mathrm{m}) \pm$ & & & 0.10 & 0.30 \\
\hline & CD @ 0.01 & & & 0.20 & 0.59 \\
\hline
\end{tabular}


Table.3 In vitro efficacy of contact and combi product fungicides on $P$. setariae

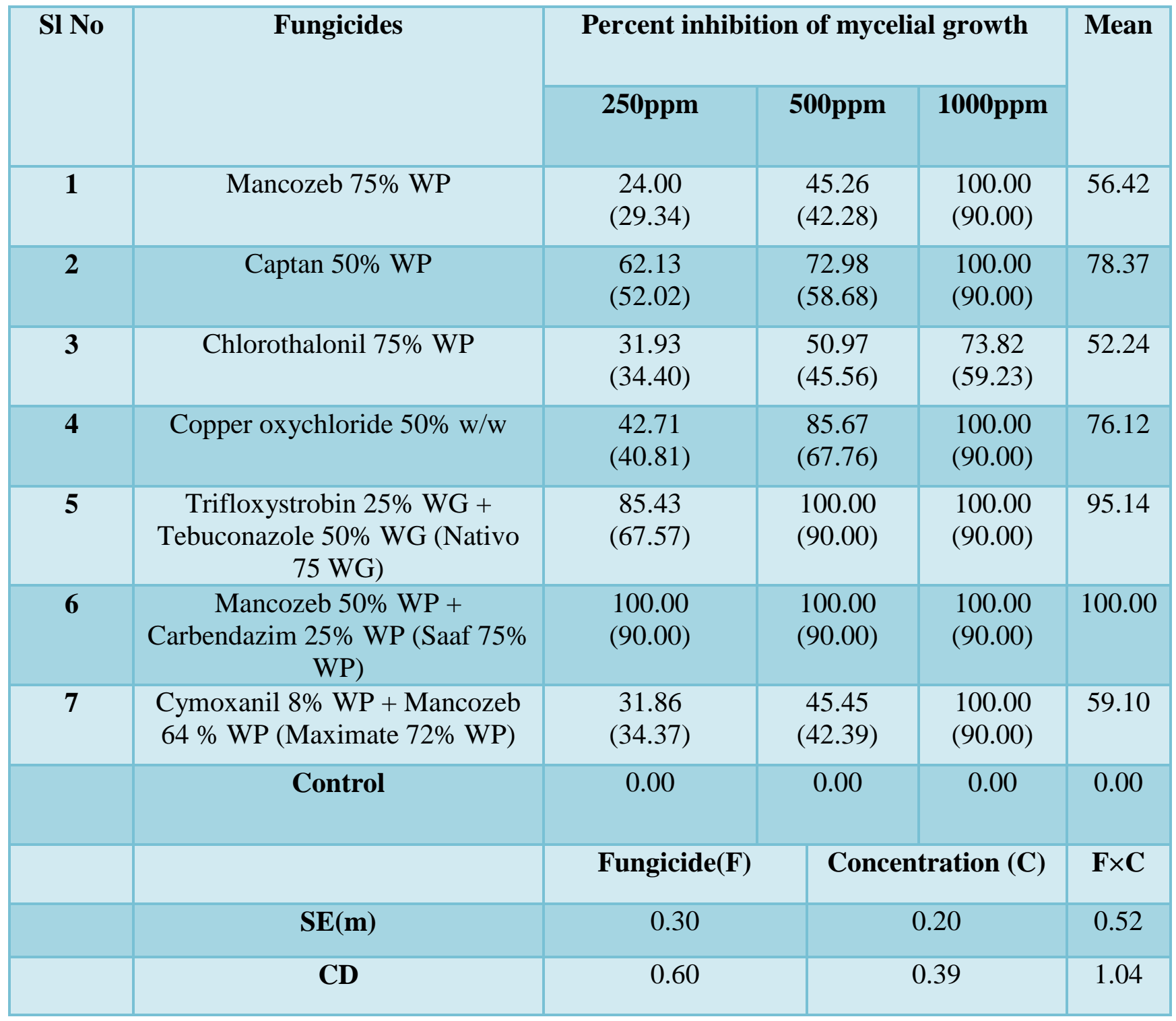


Fig.1 Per cent mycelial inhibition of $P$. setariae by different systemic fungicides

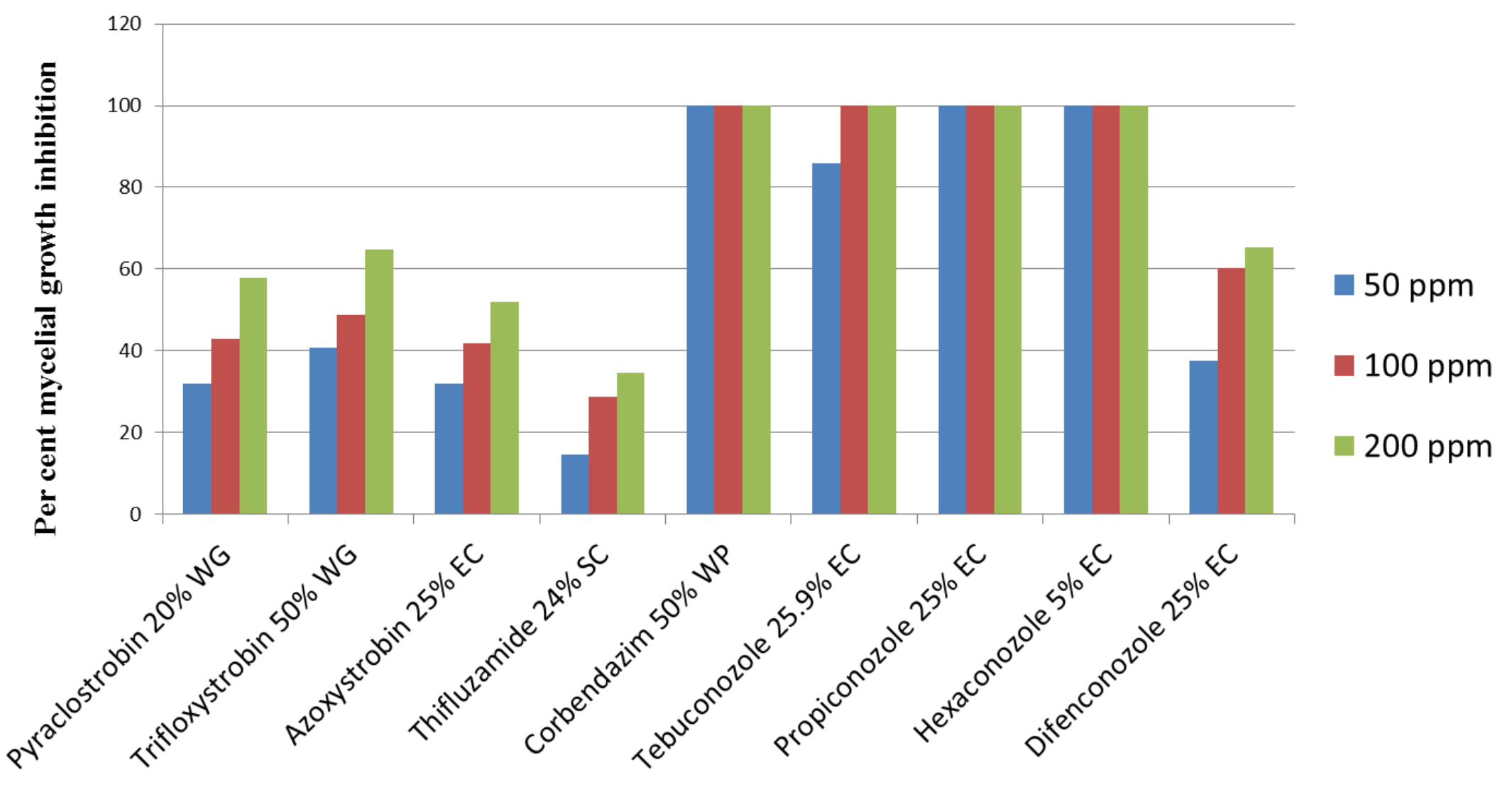

\section{Fungicides}


Fig.2 Effect of different contact and combi product fungicides on per cent mycelial growth inhibition of $P$. setariae

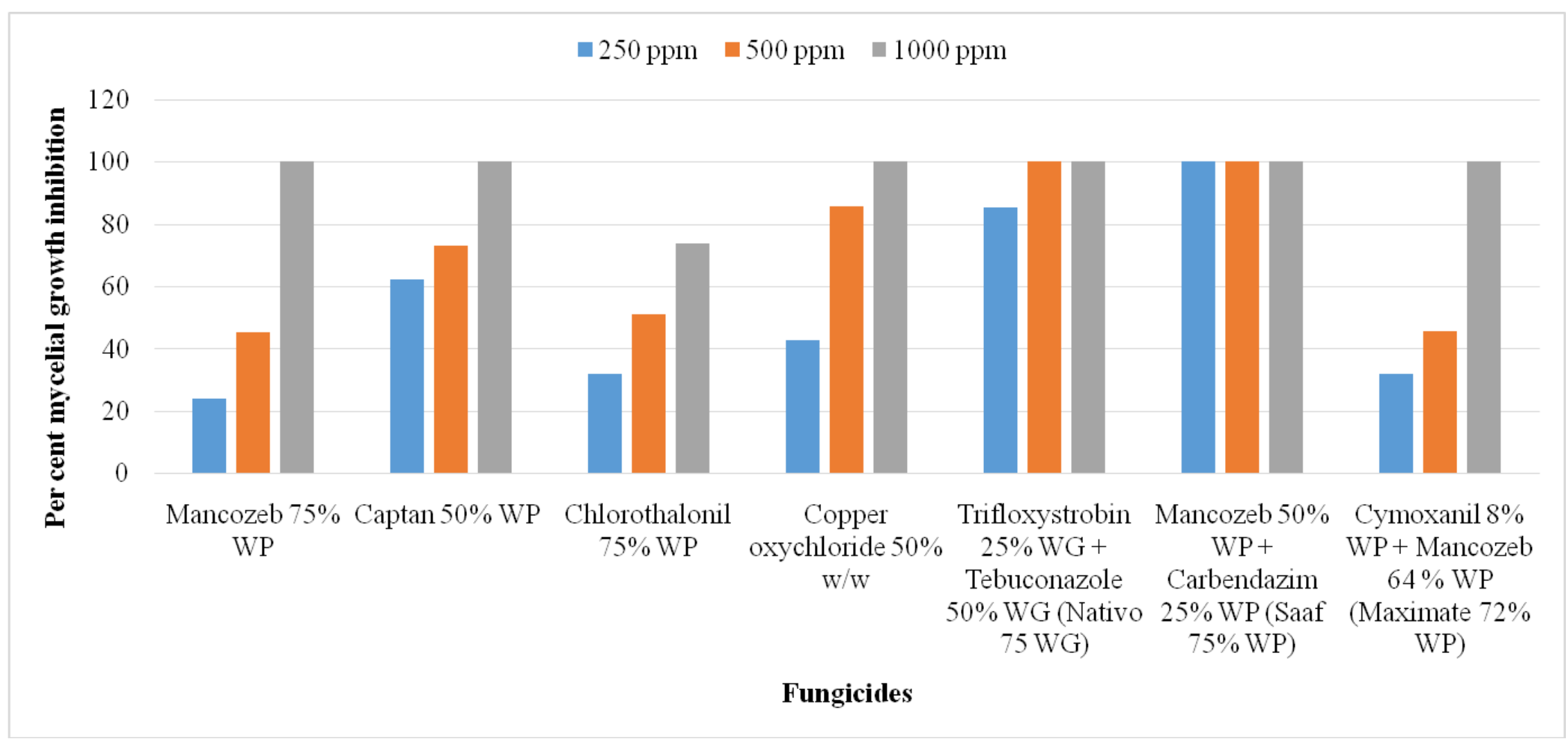


Plate.1 In vitro efficacy of different systemic fungicides against $P$. setariae
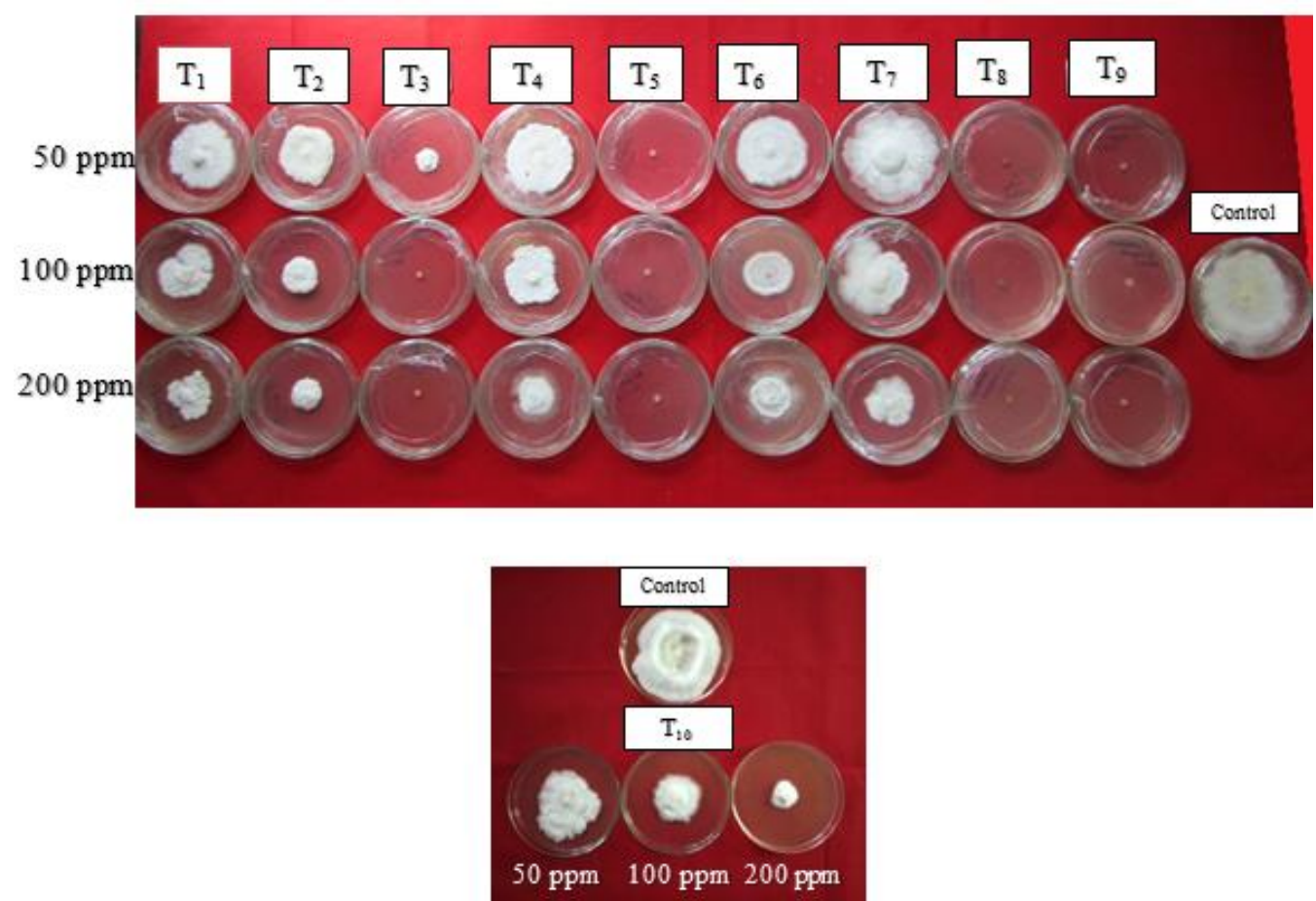

$\mathrm{T}_{1}$-Trifloxystrobin $50 \% \mathrm{WG} ; \quad \mathrm{T}_{2}$ - Difenconozole $25 \% \mathrm{EC} ; \mathrm{T}_{3}$-Tebuconozole $25.9 \% \mathrm{EC}$

$\mathrm{T}_{4}$ - Pyraclostrobin $20 \% \mathrm{WG} ; \quad \mathrm{T}_{5}$-Propiconozole $25 \% \mathrm{EC} ; \mathrm{T}_{6}$ - Azoxystrobin $25 \% \mathrm{EC}$

$\mathrm{T}_{7}$ - Thifluzamide $24 \% \mathrm{SC} ; \quad \mathrm{T}_{8}$-Corbendazim $50 \% \mathrm{WP} ; \mathrm{T}_{9}$-Hexaconozole $5 \%$ EC; $\mathrm{T}_{10}$-Tricyclozole $75 \% \mathrm{WP}$

Plate.2 In vitro efficacy of different contact and combi products fungicides against $P$. setariae

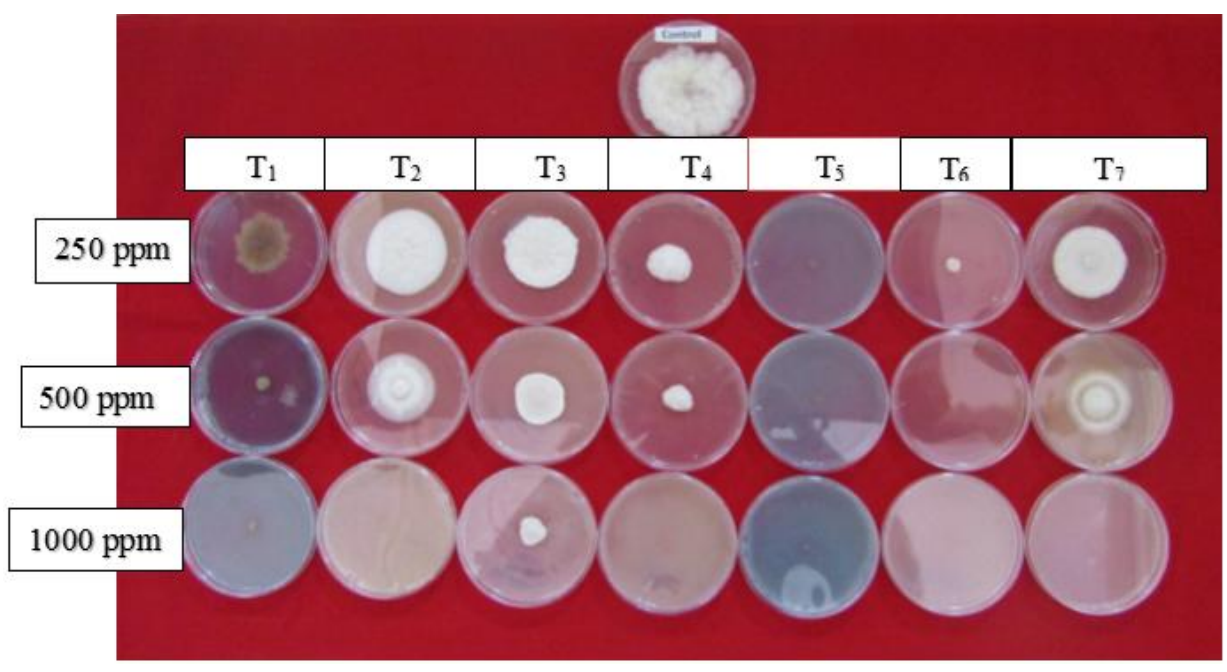

$\mathrm{T}_{1}$-Copper oxychloride 50\% w/w; $\mathrm{T}_{2}$ - Mancozeb 75\% WP; $\quad \mathrm{T}_{3}$-Chlorothalonil 75\% WP

$\mathrm{T}_{4}$ - Captan 50\% WP; $\quad \mathrm{T}_{5}$-Mancozeb 50\% WP + Carbendazim 25\% WP (Saaf 75\% WP)

$\mathrm{T}_{6}$ - Trifloxystrobin $25 \% \mathrm{WG}+$ Tebuconazole $50 \% \mathrm{WG}$ (Nativo $75 \mathrm{WG}$ )

$\mathrm{T}_{7}$ - Cymoxanil 8\% WP + Mancozeb $64 \% \mathrm{WP}$ (Maximate 72\% WP) 
Summary of the study are as follows:

Foxtail millet is most important crop next only to finger millet in importance among all the small millets. Since, it is a rich source of carbohydrates, proteins, minerals and vitamins and it has got medicinal importance with many health benefits. Therefore, foxtail is getting more importance and govt of India is giving more emphasis to increase area and production. However, this crop is affected by many biotic and abiotic constraints. Among biotic constraints leaf blast is a main constraint limiting production of foxtail millet and not much work was done on leaf blast of foxtail millet. In this context, the present study was carried out with respect to evaluation fungicides in order to generate preliminary data of effective fungicides against blast disease under in vitro condition.

Among four contact and three combi-product fungicides tested all the combi products found effective and in contact fungicides mancozeb, capton and copper oxychloride showed highest mycelial inhibition $(100 \%)$ at 1000 ppm concentration and least inhibition was observed in chlorothalonil $(73.82 \%)$ at 1000 ppm. Similarly, among systemic fungicides propiconozole, hexaconozole and carbendazim inhibited maximum mycelial growth $(100 \%)$ at all concentrations followed by tebuconazole which accounted 100 per cent mycelial growth inhibition at 100ppm and 200ppm whereas least mycelial growth inhibition was observed in case of thifluzamide $(14.69 \%)$ at 50ppm.

\section{References}

Anwar, A., Bhat, G. N. and Singhara, G. N., 2002. Management of sheath blight and blast in rice through seed treatment. Ann.Pl. Protec. Sci., 10: 285-287.

Baker, R. D., 2003. Millet production (Guide A-414), New Mexico State University.

Bhojyanaik, V. K., 2013.Studies on the blast of pearl millet caused by Pyricularia grisea (Cooke) Sacc. in northern Karnataka. M. Sc. (Agri) Thesis. University of Agricultural Sciences, Dharwad.

Choi, Y., Osada, K., Ito, Y., Nagasawa, T., Choi, M. and Nishizawa, N., 2005. Effects of dietary protein of Korean foxtail millet on plasma adinopectin, HDL-cholesterol and insulin levels in genetically type 2 diabetic mice. Biosci. Biotechnol. Biochem.,69:31-37.

Gaikwad, A. P. andD'souza, T. F., 1987.A comparative study on Pyriculariaspp. J. Maharashtra Agril.Uni.,12: 134-135.

Gohel, N. M., Chauhan, H. L. AND Mehta, A. N., 2008.Bio-efficacy of fungicides against Pyriculariaoryzaethe incitant of rice blast.J. Pl. Dis. Sci., 3(2): 189-192.

Hajano, J., Lodhi, A. M., Mumtaz, A. P.,Khanzada, M. A. and Shah, S. G., 2012.In vitro evaluation of fungicides, plant extracts and biocontrol agents against rice blast pathogen Magnaporthe oryzaeCouch. Pak. J. Bot., 44(5): 1775-1778.

Marathee, J.P., 1993. Structure and characteristics of the world millet economy. pp. 159-178. In: K.W. Riley, S.C. Gupta, A. Seetharam, and J.N. Mushonga (Ed.), Advances in small millets. Oxford and IBH Publ.Co. Pvt. Ltd., 66 Janpath, New Delhi.

Mohan, C., Amrinder, K. and Sandeep, R., 2011. In vitro evaluation of different fungicides against Pyricularia grisea. Pl. Dis. Res., 26(2): 178.

Nene, Y. L. and Thapliyal, P. N., 1973.Fungicide in Plant Diseases Control (Ed) : Oxford and IBH publishing Co. Pvt. Ltd., New Delhi, p. 325.

Netam, R. S., Bahadur, A. N., Tiwari, R. K. S. and Tiwari, U., 2013. Effect of different culture media, carbon source, nitrogen Source, temperature and $\mathrm{pH}$, level on 
the growth and sporulation of Pyricularia grisea isolate from finger millet. Res. J. Agric. Sci., 4(1): 83-86.

Rai, M., 2002. Nutritive cereals. In: Survey of Indian Agriculture. The Hindu, Chennai, Tamil Nadu, India. pp 59-62.

Sema, A. and Sarita, S., 2002.Suitability of millet-based food products for diabetics. J. Food Sci. Technol., 39:423-426.

Somashekharkonda., 2015.Investigations on leaf blast of foxtail millet $\{$ Setaria italic (1.) Beauv.\}. M. Sc. (Agri) Thesis. University of Agricultural Sciences,
Bengaluru.

Vavilov, N. I., 1926. Studies on the origin of cultivated plants. Appl. Bot. Plant Breed.,26: 1-248.

Vincent, J. M., 1947. Distribution of fungal hyphae in the presence of certain inhibitors. Nature., 159: 850.

Wright, W. G. and Finch, R. C., 1962. Firm seeds in the foxtail millets. Proc. Assoc. off. Seed. Ann. North. America., 52: 109-111.

\section{How to cite this article:}

Mallikarjuna, B., M. S. Nagaraj and Palanna, K. B. 2020. In vitro Evaluation of Fungicides against Blast of Foxtail Millet caused by Pyricularia setariae. Int.J.Curr.Microbiol.App.Sci. 9(02): 2364-2374. doi: https://doi.org/10.20546/ijcmas.2020.902.269 